\title{
ОСОБЛИВОСТІ УПРАВЛІНСЬКОГО ВПЛИВУ ПРЕЗИДЕНТА УКРАЇНИ НА СУСПІЛЬНІ ВІДНОСИНИ, ЩО СКЛАДАЮТЬСЯ У СФЕРІ ОПОДАТКУВАННЯ
}

Актуальність теми дослідження. Глибинний аналіз та зіставлення державотворчих процесів в Україні в умовах незалежності дозволяють стверджувати, що проведення політичних, економічних, соціальних реформ, спрямованих на перетворення України в сучасну європейську країну, стало важливим і нагальним у світлі загальних світових тенденцій і практики. При цьому забезпечення економічної самостійності України у світлі євроінтеграційних процесів видається можливим лише за умови створення міцної фінансової системи в Україні.

Доходи Державного бюджету України прямо залежать від величини податкових надходжень. Тому не дарма податкам і зборам, які надходять до бюджету країни, відводиться особливе місце як джерелам формування державного та місцевих бюджетів. Їм належить провідна роль у забезпеченні виконання державної функції щодо регулювання економічних процесів. При цьому величина податкових надходжень залежить від дотримання вимог чинного законодавства у сфері оподаткування.

Отже, на сучасному етапі одним із питань, яке потребує особливої уваги, є проблематика правового та інституційного впливу на забезпечення сфери оподаткування. Здійснювати належне регулювання сфери оподаткування, а також оцінити доцільність та ефективність впровадження реформ податкової системи в Україні дозволяє з'ясування особливостей інституційного механізму забезпечення сфери оподаткування України, визначення системи суб'єктів публічного адміністрування, які безпосередньо формують інституційний механізм забезпечення сфери оподаткування та з'ясування правових основ їхньої діяльності. В цьому аспекті необхідно вказати, що в умовах трансформації сфери оподаткування зазначене зумовлює необхідність дослідження теоретико-правових засад управлінського впливу Президента України на суспільні відносини, що складаються у сфері оподаткування.

Стан наукового дослідження питання. Дослідженню складних і суперечливих питань, які стосуються проблематики забезпечення сфери оподаткування в Україні, займалися теоретики та практики В.Б. Авер'янов, Є.О. Алісов, О.Ф. Андрійко, М.I. Ануфрієв, О.М. Бандурка,
В.Т. Білоус, Ю.С. Бездушна, Д.А. Бекерська, Ф.Ф. Бутинця, Д.В. Вінницький, Л.К. Воронова, П.Т. Гега, Л.В. Гурєєва, О.М. Данілов, П.В. Діхтієвський, К.Ю. Іванова, В.М. Жук, М.І. Карлін, Л.М. Касьяненко, В.І. Кашин, Ю.О. Крохіна, М.П. Кучерявенко, А.В. Кормишова, В.С. Костюченко, А.М. Новицький, В.А. Панасюк, С.Б. Пархоменко, Г.В. Петрова, В.Ю. Попович, О.А. Прийма, Д.М. Серебрянський, А.М. Соколовська, O.I. Стрельніков, B.I. Теремецький, Н.М. Ткаченко, В.С. Шестак, І.П. Яковлєв та інші. Значення наукових праць вказаних вчених не викликає ніяких сумнівів, однак дослідження ролі та місця Президента України в інституційному механізмі забезпечення сфери оподаткування здійснювалося досить фрагментарно.

Метою статті є визначення ролі та місця Президента України в інституційному механізмі забезпечення сфери оподаткування.

Виклад основного змісту. Важливим питанням сьогодення є встановлення Україною курсу на євроінтеграцію, що стало головною та безпосередньою причиною реформування положень податкового законодавства та трансформації суб'єктів публічного адміністрування сфери оподаткування, особливої уваги серед яких заслуговує діяльність Президента України. Насамперед необхідно вказати, що загальноприйнятим є поділ суб'єктів публічної адміністрації на: 1) органи державної виконавчої влади; 2) органи місцевого самоврядування; 3) суб'єктів делегованих повноважень.

Конкретизуючи вказану диференціацію відповідно до сфери оподаткування, а також враховуючи позиції окремих дослідників, інституційний механізм забезпечення сфери оподаткування доцільно формувати з функціонального відображення діяльності таких суб'єктів публічної адміністрації: 1) органи державної виконавчої влади; 2) органи місцевого самоврядування [7]; 3) суб'єкти делегованих повноважень, якими у сфері оподаткування можуть виступати інститути громадянського суспільства; 4) суб'єкти, яких не віднесено до органів державної виконавчої влади та місцевого самоврядування, але наділено окремими повноваженнями щодо забезпечення управлінського впливу у вказаній сфері. До цієї групи можна включити Верховну Раду України, Верховну Раду 
АРК, Президента України, Національний Банк України, Уповноваженого Верховної Ради з прав людини, військово-цивільні адміністрації тощо.

3 огляду на обсяг повноважень, які надано суб'єктам публічної адміністрації у сфері оподаткування, доцільно класифікувати зазначених суб'єктів на тих, які:

1) здійснюють інституційне забезпечення на загальнодержавному рівні (Кабінет Міністрів України, Міністерство фінансів України, Державна митна служба України, Державна податкова служба України, громадські ради при органах влади загальнодержавного значення, всеукраїнські громадські організації, Верховна Рада України, Президент України, Національний Банк України, Уповноважений Верховної Ради з прав людини);

2) здійснюють інституційне забезпечення на місцевому рівні (територіальні органи Державної митної служби України та Державної податкової служби України, місцеві державі адміністрації, органи місцевого самоврядування, громадські ради при місцевих органах влади, місцеві громадські організації, Верховна Рада АРК, військово-цивільні адміністрації).

Отже, Президент України в інституційному механізмі забезпечення сфери оподаткування займає особливе місце, адже є суб'єктом, якого не віднесено до органів державної виконавчої влади та місцевого самоврядування, але якого наділено окремими повноваженнями щодо забезпечення управлінського впливу у вказаній сфері, здійснює інституційне забезпечення сфери оподаткування на загальнодержавному рівні.

Зазначимо, що закріплення правового статусу Президента України в Основному Законі та наділення його виключною компетенцією як глави держави сприяють визнанню за ним повноважень саме конституційно-правового характеру. Однак детальне вивчення правового статусу Президента України дає підстави розцінювати його не лише в контексті представника інституту президенства, а ще і як повноцінного суб'єкта публічної адміністрації. Дійсно, Президенту України відведено місце серед суб'єктів публічної адміністрації, яких не віднесено до органів державної виконавчої влади та місцевого самоврядування, але яких наділено окремими повноваженнями щодо забезпечення управлінського впливу в різних сферах суспільних відносин, включно зі сферою оподаткування.

Характеризуючи правовий статус Президента України, необхідно вказати, що вперше посаду Президента в Україні було запроваджено Законом «Про Президента Української РСР» (далі - Закон) від 05.07.1991, відповідно до положень ст. 1 якого Президент визнавався найвищою посадовою особою Української Держави та главою виконавчої влади. Положеннями ст. 7 вказаного Закону було передбачено, що Президент Української РСР має право скасовувати постанови та розпорядження Кабінету Міністрів Української РСР, Уряду Кримської АРСР, акти міністерств Української РСР, інших підвідомчих йому органів, виконавчих комітетів місцевих Рад народних депутатів Української РСР, а також зупиняти дію рішень органів виконавчої влади Союзу РСР на території Української РСР, якщо вони суперечать Конституції Української РСР і законам Української РСР [8]. Тотожні положення закріплювала і Конституція Української РСР 1978 року у ст. $114^{1}$ [2].

На сучасному етапі розвитку Української держави правовий статус Президента України визначено Конституцією України, в якій йому відведено окремий розділ. Аналізуючи положення ст. 102 Основного Закону, можна дійти висновку, що на Президента України покладено три важливі ролі (функціі):

1) Президент України є главою держави і виступає від її імені;

2) Президент України є гарантом державного суверенітету, територіальної цілісності України, додержання Конституції України, прав і свобод людини і громадянина;

3)Президент Україниєгарантом реалізаціїстратегічного курсу держави на набуття повноправного членства України в Європейському Союзі та в Організації Північноатлантичного договору [3].

Таким чином, визначаючи Президента України главою держави та закріплюючи республіканську (змішану) форму правління, Конституція України, на відміну від попередніх нормативно-правових актів, якими було врегульовано правовий статус Президента, фактично виводить його посаду за межі тріади гілок єдиної державної влади.

Особливий правовий статус і неналежність Президента України до жодної з гілок влади не означають невизначеності його юридичного положення. Навпаки, Президент України, враховуючи його повноваження та комплексний характер взаємодії з іншими гілками влади, $є$ сполучною ланкою між усіма гілками влади як центр, що налагоджує спільні взаємні зусилля. Тобто, місце Президента України має бути не «над», а «між» гілками влади як інтеграційного чинника їхньої співпраці [5]. У зв'язку з цим саме Президента України наділено широкими повноваженнями у сфері взаємовідносин із законодавчою, виконавчою та судовою гілками влади, він виступає своєрідним арбітром і забезпечує існування в державі системи стримувань і противаг із метою недопущення абсолютизації влади окремого державного органу.

Слід зазначити, що ціннісно-функціональне призначення Президента України в державі та суспільстві розкривається через його місце в системі державної влади України і визначається такими характеристиками: 
1) Президент України в системі поділу державної влади не належить ані до законодавчої, ані до виконавчої, ані до судової влади, займаючи особливе, самостійне місце в державному механізмі, але за змістом своїх повноважень Президент України є найбільш наближеним до виконавчої влади;

2) влада Президента України є похідною від влади народу України, який є носієм суверенітету та єдиним джерелом влади в Україні [3, ч. 2 ст. 5], що забезпечує формальну незалежність Президента України від інших вищих органів державної влади;

3) Президент України забезпечує єдність державної влади і державної політики, цілісність державного механізму;

4) Президент України є рівноправним суб'єктом у системі державної влади;

5) Президент України зобов'язаний діяти лише на підставі, в межах повноважень і у спосіб, які передбачено Конституцією та законами України [3, ч. 2 ст. $19 ; 4]$.

Слід звернути увагу і на те, що, розцінюючи Президента України як особливого суб'єкта, який реалізує публічне адміністрування, варто констатувати, що найбільший обсяг його повноважень закріплено саме у сфері виконавчої влади. Так, відповідно до положень п.п. 15 і 16 ст. 106 Конституції України Президент України має право скасовувати акти Кабінету Міністрів України й акти Ради Міністрів Автономної Республіки Крим, рішення голів місцевих державних адміністрацій, що суперечать Конституції та законам України, іншим актам законодавства України. При цьому вказаними актами може бути врегульовано будь-яку сферу суспільних відносин, включно зі сферою оподаткування. Крім того, як передбачено ст. 137 Конституції України, з мотивів невідповідності нормативно-правових актів Верховної Ради Автономної Республіки Крим Конституції України та законам України Президент України може зупиняти дію таких нормативно-правових актів Верховної Ради Автономної Республіки Крим з одночасним зверненням до Конституційного Суду України щодо їх конституційності [3].

Підтвердженням превалювання більшості повноважень Президента України у сфері виконавчої влади можна вважати й те, що у разі дострокового припинення повноважень Президента України відповідно до положень ст.ст. 108-111 Конституції України виконання обов'язків Президента України на період до обрання і вступу на пост нового Президента України покладається на Прем'єр-міністра України. При цьому Прем'єр-міністр України у період виконання ним обов'язків Президента України не може здійснювати повноваження, які передбачено п.п. 2, 6, 8, 10-12, 14-16, 22, 25, 27 ст. 106 Конституції України [3].
Отже, загалом перелік повноважень Президента України визначено у ст. 106 Основного Закону [3] і він налічує 31 пункт. При цьому, враховуючи позиції окремих дослідників, можна констатувати, що наразі в юридичній науці існує кілька підходів до класифікації повноважень Президента України. Перший полягає у виокремленні повноважень щодо: 1) формування виконавчої влади; 2) визначення змісту та спрямування iii функціонування; 3) забезпечення законності у сфері державного управління [6].

Другий підхід представлено, наприклад, авторами підручника «Загальне адміністративне право», які поділяють повноваження Президента України у сфері публічного адміністрування на: а) кадрові; б) забезпечувальні; в) контрольні [1]. Розглянемо більш детально вказану класифікацію:

1. Кадрові повноваження: внесення подання про призначення Верховною Радою України Прем'єр-міністра України, подання про призначення Міністра оборони України, Міністра закордонних справ України; призначення на посади та звільнення з посад половини складу Ради Національного банку України; призначення на посади та звільнення з посад половини складу Національної ради України з питань телебачення і радіомовлення; внесення до Верховної Ради України подання про призначення на посаду та звільнення 3 посади Голови Служби безпеки України; присвоєння вищих військових чинів тощо.

2. Забезпечувальні повноваження: створення консультативних, дорадчих та інших допоміжних органів і служб; ухвалення рішень про введення в Україні або в окремих її місцевостях надзвичайного стану, а також оголошення в разі потреби окремих місцевостей України зонами надзвичайної екологічної ситуації з подальшим затвердженням цих рішень Верховною Радою України; ухвалення рішення про прийняття до громадянства України та припинення громадянства України, про надання притулку в Україні тощо.

3. Контрольні повноваження: зупинення дії актів Кабінету Міністрів України з мотивів їх невідповідності Конституції України з одночасним зверненням до Конституційного Суду України щодо їх конституційності; призначення всеукраїнського референдуму щодо змін Конституції України, проголошення всеукраїнського референдуму за народною ініціативою; скасування актів Ради міністрів Автономної Республіки Крим тощо.

Специфікуючи сказане до сфери оподаткування, доходимо висновку, що повноваження Президента України щодо забезпечення сфери оподаткування залежно від функціонального призначення доцільно класифікувати на:

1) повноваження щодо контролю;

2) повноваження щодо організації органів виконавчої влади; 
3) повноваження щодо керівництва;

4) повноваження щодо встановлення окремих станів;

5) інші повноваження.

Вказане свідчить про те, що правовий статус Президента України має подвійний характер. По-перше, для галузі податкового права конституційні повноваження Президента України щодо гарантування державного суверенітету, територіальної цілісності України, дотримання Конституції України, прав і свобод людини та громадянина є вихідними положеннями, які мають розвиватися наукою податкового права та безпосередньо забезпечуватися органами та посадовими особами виконавчої влади та місцевого самоврядування. По-друге, деякі повноваження глави держави щодо формування органів виконавчої влади, контролю за їхньою діяльністю, забезпечення національної безпеки та інші дають підстави стверджувати, що інститут Президента в Україні законодавчо є таким, якого наділено функціями виконавчої влади [1].

Висновки. Отже, особливості управлінського впливу Президента України на суспільні відносини, що складаються у сфері оподаткування, як глави держави полягають у здійсненні керівництва фінансовою діяльністю відповідно до ст. 106 Конституції України. Крім того, Президента України наділено повноваженням скасовувати акти Кабінету Міністрів України з мотивів невідповідності Основному Закону, правом підписувати закони, які прийнято Верховною Радою України, і правом «вето» щодо прийнятих Верховною Радою України законів у сфері оподаткування.

\section{Jimepamypa}

1. Адміністративне право України. Повний курс : підручник / Галунько В., Діхтієвський П., Кузьменко О., Стеценко С. та ін. Херсон : ОЛДІ-ПЛЮС, 2018. $446 \mathrm{c}$.

2. Конституція (Основний Закон) України : Закон Верховної Ради УРСР від 20.04.1978 № 888-IX. URL: https://zakon.rada.gov.ua/laws/show/888-09\#Text.

3. Конституція України : Закон України від 28.06.1996 № 254к/96-ВР. Відомості Верховної Ради. 1996. № 30. Ст. 141.

4. Крусян А.Р. Президент України: особливості конституційно-правового статусу та тенденції його удосконалення. Юридичний вісник : щоквартальний журнал. 2011. № 2. С. 49-57.

5. Кузнєцова О.В. Взаємодія інституту президентства з іншими гілками влади (на прикладі України, Росії та Білорусі). Гілея : науковий вісник. 2011. № 45 URL: http://www.nbuv.gov.ua/portal/Soc_Gum/ Gileya/20 11 45/Gileya45/P6 doc.pdf.

6. Мацелик Т.О. Президент України як суб'єкт адміністративного права. Вісник Академії митної служби України. Серія: Право. 2011. № 2. С. 68-72.

7. Про місцеве самоврядування в Україні : Закон України від 21.05.1997 № 280/97-BP. URL: https://zakon.rada.gov.ua/laws/show/280/97. $\%$ D0 $\%$ B2 $\%$ D1 $\%$ 80/stru\#Stru.
8. Про Президента Української РСР : Закон Української РСР від 05.07.1991 № 1295-XII. URL: https://zakon.rada.gov.ua/laws/show/1295-12\#Text.

\section{Анотація}

Янушевич Я. В. Особливості управлінського впливу Президента України на суспільні відносини, що складаються у сфері оподаткування. - Стаття.

У статті розглянуто теоретико-правові засади управлінського впливу Президента України на суспільні відносини, що складаються у сфері оподаткування. Встановлено, що детальне вивчення правового статусу Президента України дає підстави розцінювати його не лише в контексті представника інституту президенства, а ще і як повноцінного суб'єкта публічної адміністрації.

Акцентовано увагу на тому, що ціннісно-функціональне призначення Президента України в державі та суспільстві розкривається через його місце в системі державної влади України і визначається такими характеристиками: у системі поділу державної влади не належить ані до законодавчої, ані до виконавчої, ані до судової влади, займаючи особливе самостійне місце в державному механізмі, але за змістом своїх повноважень Президент України є найбільш наближеним до виконавчої влади; влада Президента України є похідною від влади народу України, який є носієм суверенітету та єдиним джерелом влади в Україні, що забезпечує формальну незалежність Президента України від інших вищих органів державної влади; забезпечує єдність державної влади і державної політики, цілісність державного механізму; є рівноправним суб'єктом у системі державної влади; зобов'язаний діяти лише на підставі, в межах повноважень і у спосіб, які передбачено Конституцією та законами України.

Доведено, що Президент України в інституційному механізмі забезпечення сфери оподаткування займає особливе місце, адже є суб̆'єктом, якого не віднесено до органів державної виконавчої влади та місцевого самоврядування, але якого наділено окремими повноваженнями щодо забезпечення управлінського впливу у вказаній сфері, здійснює інституційне забезпечення сфери оподаткування на загальнодержавному рівні.

Ключові слова: інституційний механізм, повноваження, Президент України, суб'єкт публічної адміністрації, сфера оподаткування.

\section{Summary}

Ianushevych Ia. V. Peculiarities of the management influence of the President of Ukraine on social relations being formed in the taxation sphere. - Article.

The paper reviews the theoretical and legal principles of the management influence of the President of Ukraine on social relations that are being formed in the taxation sphere. It has been established that a detailed study of the legal status of the President of Ukraine makes grounds to assess it not only in terms of a representative of the presidency institution but also as a full-fledged public administration subject.

It has been emphasized that the value-based and functional assignment of the President of Ukraine in the state and society becomes clear through his place in the state power system of Ukraine and is characterized by the following: it does not belong to the legal or executive or judicial powers an occupies a special, independent place in the state mechanism, however, according to the content of his authority, the President of Ukraine is closer to the 
executive power; the power of the President of Ukraine is derived from the people of Ukraine that is a carrier of sovereignty and the only source of power in Ukraine, which ensures the formal independence of the President of Ukraine from other supreme bodies of the state power; provides for the unity of the state power and state policy, and integrity of the state mechanism; is an equal subject of the state power system; and is obliged to act on the basis, within the limits of authority and by the way envisaged by the Constitution and laws of Ukraine.
It is proved that the President of Ukraine occupies a special place in the institutional mechanism supporting the taxation sphere because he is the subject that does not refer to the state executive bodies and local self-government bodies but has separate powers of the management influence in said sphere and performs the institutional support of the taxation sphere at the national level.

Key words: institutional mechanism, authority, President of Ukraine, public administration subject, taxation sphere. 